\title{
Trade Costs and Location of Foreign Firms in China ${ }^{*}$
}

\author{
Mary Amiti* \\ International Monetary Fund and CEPR
}

\author{
Beata Smarzynska Javorcik $^{\#}$ \\ World Bank and CEPR
}

\begin{abstract}
This study examines the determinants of entry by foreign firms, using information on 515 Chinese industries at the provincial level during 1998-2001. The analysis, rooted in the new economic geography, focuses on market and supplier access within and outside the province of entry, as well as production and trade costs. The results indicate that market and supplier access are the most important factors affecting foreign entry. Access to markets and suppliers in the province of entry matters more than access to the rest of China, which is consistent with market fragmentation due to underdeveloped transport infrastructure and informal trade barriers.
\end{abstract}

JEL Classifications: F1 F23.

Keywords: foreign direct investment, trade costs, market access, supply access.

World Bank Policy Research Working Paper 3564, April 2005

The Policy Research Working Paper Series disseminates the findings of work in progress to encourage the exchange of ideas about development issues. An objective of the series is to get the findings out quickly, even if the presentations are less than fully polished. The papers carry the names of the authors and should be cited accordingly. The findings, interpretations, and conclusions expressed in this paper are entirely those of the authors. They do not necessarily represent the view of the World Bank, its Executive Directors, or the countries they represent. Policy Research Working Papers are available online at http://econ.worldbank.org.

\footnotetext{
- We would like to thank Caroline Freund, Mary Hallward-Driemeier, Will Martin, Stephen Redding, John Romalis, Tony Venables, Shang-Jin Wei, and participants at the Workshop on National Market Integration (World Bank and Development Research Council) in Bejing, September 2003, the Workshop on China's Economic Geography and Regional Development in Hong Kong, December 2003, and the World Bank/IMF seminars for helpful comments and suggestions. We are also grateful to the China National Bureau of Statistics (NBS) and the China Customs Office for supplying us with the data, and to Sourafel Girma for providing some additional data.

* The International Monetary Fund, 700 19th Street, Washington DC 20431. Ph (202) 623 7767. Email: mamiti@imf.org.

${ }^{\#}$ The World Bank, 1818 H Street, N.W., MSN MC3-303, Washington, DC 20433. Phone: (202) 458-8485.

E-mail: bjavorcik@worldbank.org.
} 


\section{Introduction}

Governments all over the world spend large sums of money to entice foreign direct investment (FDI), usually offering generous tax incentives. It is generally expected that foreign firms will generate positive externalities on domestic firms, particularly in developing countries. For example, Javorcik (2004) provides evidence consistent with the existence of positive interindustry spillovers from foreign firms in Lithuania. However, the evidence on the success of tax incentives in attracting FDI is rather mixed (see Desai et al. 2004), which raises the question of what factors in fact influence where foreign firms locate.

The theoretical literature on firm location emphasizes a tension between production costs and access to large final goods markets and input suppliers. Recent work by Krugman and Venables (1995), and Markusen and Venables $(1998,2000)$ shows that while the market size is an important consideration for firms, the larger the markets the higher the cost of immobile factors. The relative strength of these factors in determining location depends critically on trade costs. The view that both market size as well as access to intermediate inputs affect

foreign investors' decisions is supported by anecdotal evidence. For instance, a manager of Salcomp, a Finish mobile company, justified the interest of the company in China by stating that "Our markets are in China, our components are there and wages are much lower..." (Financial Times, May 2004).

Building on the predictions of the theoretical literature on economic geography, this study examines the relative importance of market access, supplier access, trade costs and factor costs on the entry of foreign firms into China. While FDI determinants have been 
analyzed extensively (for example, see Caves 1982; and Markusen 1995), little attention has been paid to the new economic geography aspects of the investment decision. Notable exceptions are studies by Head and Mayer (2004) and Head and Ries (1996). The former study focuses on market access and shows that there exists a positive correlation between entry of Japanese firms into the European Union (EU) and market potential measures, which aggregate demand from multiple EU regions adjusted by distance. The latter study takes into account market and supplier access as determinants of foreign entry into China, but does not incorporate any spatial aspects. That is, their proxies for the availability of inputs are the total number of industrial enterprises and the total value of industrial output within the province of foreign entry in China. ${ }^{1}$

Our analysis extends the literature in several dimensions. First, we consider the importance of both market and supplier access in determining foreign entry, taking into account spatial aspects. We allow for the possibility that firms purchase inputs not only from within their own province, but also from other provinces within China and from the rest of the world. Second, our measures of market and supplier access take into account the varying degrees of inter-industry linkages. For example, proximity to a steel plant is likely to be more valuable to a car producer than a textile manufacturer. Third, by incorporating all the key factors highlighted in the new economic geography literature, we are able to provide an assessment of the relative importance of production costs and market size effects in attracting new entry.

China is a particularly interesting country in which to analyze FDI flows. It was among

\footnotetext{
${ }^{1}$ Head and Ries (1996) assume that firms buy all their inputs locally and they do not distinguish in their analysis between various degrees of input availability in different industries.
} 
the top FDI recipients in the world during the period under study, receiving US $\$ 165$ billion of direct investment flows between 1998 and 2001 (World Investment Report 2002, Annex Table B3). Rising inequality between Chinese provinces has been of growing concern to the Chinese government which has introduced a number of policies aimed at mitigating this development. ${ }^{2}$ With over 90 percent of foreign investment being directed to the coastal regions, the influx of FDI has widened regional disparities between coastal and central regions within China. By providing an assessment of the importance of market access and supplier access relative to production costs, this study provides some guidance on the kinds of policy instruments that would be most successful in attracting FDI to disadvantaged regions.

In addition to an intrinsic interest in determinants of FDI flows into China, our study sheds some light on the economic impact of inter-provincial barriers to trade. There exists evidence suggesting that in an effort to protect industries from competition, local governments in China are erecting barriers to entry of goods from other provinces. The presence of such barriers was reported by Kumar (1994) and Young (2000) and is consistent with anecdotal evidence. For instance, managers of Chinese firms confirmed that they have indeed experienced some difficulties in accessing markets in other provinces. A manager of a medical manufacturing plant reported that the shipments to other provinces are occasionally stopped by local rail officials for 2 to 4 weeks for no apparent reason. The administrative units of industry and commerce department were reportedly obstructing access to markets through

\footnotetext{
${ }^{2}$ Strong economic growth experienced by China during this time did not benefit all provinces equally. For instance, while in 1999 the GDP of coastal provinces increased by $7.2 \%$, central and western provinces experienced a growth rate of only 3.8 and $4.7 \%$, respectively. In the same year, coastal provinces accounted for $60 \%$ of Chinese GDP and almost three-quarters of national output of manufactured goods. See Amiti and Wen (2001) for a discussion on regional inequality in earlier years and the spatial distribution of manufacturing industries in 1995.
} 
audits or local registration requirements. ${ }^{3}$ Unfortunately, it is not possible to directly measure such barriers. As it is illegal to impose trade restrictions, the measures adopted to protect local industries from competition are usually more subtle than a direct border tax. Thus the only way to assess the significance of such barriers is indirectly, as is the case in our study. ${ }^{4}$

Our analysis is based on a comprehensive data set provided by the China National Bureau of Statistics (NBS) covering nearly all manufacturing industries, at a highly disaggregated level (515 industries) in 29 Chinese provinces, during the period 1998-2001. ${ }^{5}$ Using the information on the value of output by industry and province, the national input/output table and inter-provincial distances we construct measures of market access and supplier access. We also create industry-specific measures of tariff rates on imported inputs. We then relate these measures to the change in the number of foreign firms in each province and industry. We also control for a variety of provincial characteristics. Proxies for trade costs at the provincial level include transport infrastructure and openness to international trade. Production costs are proxied by provincial wages and electricity prices. We consider separately market access and supplier access within and outside the province of foreign

\footnotetext{
${ }^{3}$ Interviews with firms and government officials were conducted by Amiti in five different provinces in October 2001.

${ }^{4} \mathrm{~A}$ number of researchers have tried to estimate the size of these provincial trade barriers using indirect measures (see Poncet 2003, Young 2000, Naughton 1999, Huang and Wei 2003, and Bai et al. 2004), but none of them has considered the consequences of such barriers. None of the studies has ruled out the existence of provincial border barriers and some have found evidence that such barriers have increased over time.

${ }^{5}$ Other studies on the determinants of FDI in China rely either on information on provincial FDI stocks (Cheng and Kwan, 2000), or on the Almanac of China's Foreign Economic Relations and Trade which lists entry of individual firms (Head and Ries 1996, Dean, Lovely and Wang, 2002). The latter data set is, however, limited in coverage as it includes only about 10 percent of new foreign firms, focuses exclusively on joint ventures and stopped being published in 1996. It is also unclear what criteria were used to select a particular sub-sample of all foreign investors for publication.
} 
entry. A lower magnitude of the coefficients pertaining to trade outside the province of entry relative to trade within the province would suggest that the internal trade barriers may be restricting access of foreign investors to suppliers and customers in other regions.

The results indicate that market access and supplier access are the most important factors affecting FDI inflows. Doubling either market access or supplier access is associated with a $40 \%$ increase in the entry of foreign firms. The presence of customers and suppliers in the province of entry matters much more than market and supplier access to the rest of China, which is consistent with the presence of inter-provincial barriers to trade. Further, our analysis suggests that provinces which are more open to foreign trade attract more foreign firms. Similarly, the availability of infrastructure is positively correlated with foreign entry. Although production costs also play a significant role in determining the location of foreign investment, the magnitude of these effects is around half that of the market and supplier access effects. A doubling of wages or electricity prices reduces entry of foreign firms by $17 \%$ and $22 \%$, respectively. Thus, our results suggest that local governments may do well by reducing inter-provincial barriers, and hence increasing the extent of market and supplier access in surrounding provinces, in order to attract foreign investment.

The rest of the paper is organized as follows. Section 2 develops the formal model. Section 3 provides background information on China and details of the data sources. Section 4 presents the results, and section 5 concludes. 


\section{Theory}

We derive our estimating equation from a new economic geography model, based on Krugman and Venables (1995) and Amiti $(2005)^{6}$. Firms are assumed to compete in a monopolistically competitive environment, with each firm producing a differentiated variety. All varieties of final goods enter symmetrically into the consumer's utility function and all varieties of intermediate inputs enter symmetrically in the firm's cost function. Profits of a single representative firm in industry $i$ in province $p$ are given by

$$
\pi_{p}^{i}=p_{p}^{i} x_{p}^{i}-w_{p}^{\alpha} r_{p}^{\beta}\left(P_{p}^{u}\right)^{\mu^{i}}\left[b^{i} x_{p}^{i}\right]-F
$$

The total cost function comprises a fixed cost, $F$, a constant cost, $b^{i}$, and factor prices, where $w_{p}$ is the wage in province $p, r_{p}$ is the price of capital in province $p$ or any other factor of production, and $P_{p}^{u}$ is the intermediate input price index. It is defined as

$$
P_{p}^{u}=\left[\sum_{l=1}^{P} n_{l}^{u}\left(p_{l}^{u} t_{l p}^{u}\right)^{1-\sigma^{u}}\right]^{\frac{1}{1-\sigma^{u}}} .
$$

The transport cost, $t_{l p}^{i}$, of shipping a good from province $l$ to $p$ is modelled as Samuelsonian iceberg costs, with $t \geq 1$. This means that a proportion of imported inputs, $1-\frac{1}{t}$, melts in transit. Hence, to deliver one unit of any good from one province to another $t$ units must be shipped as only a fraction $\frac{1}{t}$ arrives. If $t=1$ there is free trade and if $t=\infty$ there is no trade.

The fob producer price is given by profit maximization, which gives the usual marginal revenue equals marginal cost condition, with prices proportional to marginal cost:

\footnotetext{
${ }^{6}$ Amiti (2005) extends Krugman and Venables (1995) from a one-factor model to a two-factor model, thus allowing for different production stages to vary in factor intensities.
} 


$$
p_{p}^{i}=w_{p}^{\alpha} r_{p}^{\beta}\left(P_{p}^{u}\right)^{\mu^{i}} b^{i} \theta^{i}, \quad \theta^{i}=\frac{\sigma^{i}}{\sigma^{i}-1}
$$

The mark-up over marginal cost, $\theta^{i}$, depends on the elasticity of substitution $\sigma^{i}$.

Output of each firm in industry $i$ in province $p, x_{p}^{i}$, is sold to consumers and firms located within province $p$, in other provinces within China, and to the rest of the world. Product market clearing conditions give

$$
x_{p}^{i}=\sum_{l=1}^{P} c_{p l}^{i}+\sum_{c=1}^{C} c_{p w}^{i} .
$$

Demand for industry $i$ goods produced in province $p$ is given by

$$
c_{p l}^{i}=\left(p_{p}^{i}\right)^{-\sigma^{i}}\left(t_{p l}^{i}\right)^{1-\sigma^{i}} E_{l}^{i}\left(P_{l}^{i}\right)^{\sigma^{i}-1}
$$

Expenditure on industry $i, E^{i}$, not only comes from consumers but also from downstream firms,

$$
E_{l}^{i}=s_{l}^{i} Y_{l}+\mu^{i} n_{l}^{d} p_{l}^{d} x_{l}^{d}
$$

Downstream firms spend a proportion $\mu$ of their total revenue, $n_{l}^{d} p_{l}^{d} x_{l}^{d}$, on goods produced by industry $i$ (the second term in equation 2.6). Demand from downstream firms is derived using Shepard's lemma on the price index (as shown in Dixit and Stiglitz, 1977).

Summing across all locations within China and the rest of the world, we derive aggregate demand, and setting it equal to supply gives

$$
x_{p}^{i}=\left(p_{p}^{i}\right)^{-\sigma^{i}}\left\{\sum_{l=1}^{P}\left(t_{p l}^{i}\right)^{1-\sigma^{i}} E_{l}^{i}\left(P_{l}^{i}\right)^{\sigma^{i}-1}+\sum_{p=1}^{W}\left(t_{p w}^{i}\right)^{1-\sigma^{i}} E_{w}^{i}\left(P_{w}^{i}\right)^{\sigma^{i}-1}\right\} .
$$


Substituting in the product market clearing condition (2.7) and the profit maximizing price (2.3) into the profit function, (2.1), gives

$$
\pi_{p}^{i}=\left(w_{p}^{\alpha} r_{p}^{\beta}\left(P_{p}^{u}\right)^{\mu^{i}}\right)^{1-\sigma^{i}}\left(\theta^{i}-1\right)\left(\theta^{i}\right)^{1-\sigma^{i}}\left[\left\{\sum_{l=1}^{P+W}\left(t_{p l}^{i}\right)^{1-\sigma^{i}} E_{l}^{i}\left(P_{l}^{i}\right)^{\sigma^{i}-1}\right\}\right]-F
$$

It is assumed that free entry and exit of firms ensures zero profits in equilibrium. Firms enter when profits are positive and exit when profits are negative. Any exogenous changes to, say, trade costs would affect profits and hence the number of firms in each location. We allow all variables to be time varying hence entry can be written as a function of the change in profits:

$$
\Delta n_{p}^{i}=n_{p, t}^{i}-n_{p, t-1}^{i}=f\left(\pi_{p, t}^{i}-\pi_{p, t-1}^{i}\right)
$$

Note that profits, inclusive of the fixed $\operatorname{cost} \pi^{\prime}=\pi+F$, if $F$ is small then $\ln (\pi+F) \simeq \ln (\pi)$, hence taking natural logs of equation 2.8 we have ${ }^{7}$

$$
\begin{aligned}
\ln \pi_{p, t}^{i}= & \alpha^{i}\left(1-\sigma^{i}\right) \ln w_{p, t}+\beta\left(1-\sigma^{i}\right) \ln r_{p, t}+\mu\left(1-\sigma^{i}\right) \ln P_{p, t}^{u} \\
& +\nu_{I}+\nu_{t}+\ln \left\{\sum_{l=1}^{P+W}\left(t_{p l}^{i}\right)^{1-\sigma^{i}} E_{l}^{i}\left(P_{l}^{i}\right)^{\sigma^{i}-1}\right\},
\end{aligned}
$$

where $\nu_{I}$ represents industry fixed effects such as the degree of market power, $\theta_{i}$, and $\nu_{t}$ represents time fixed effects. Taking first differences, denoted by $\Delta$, these fixed effects are

\footnotetext{
${ }^{7}$ Note that in Krugman and Venables (1995), the fixed cost is also a function of the factor prices and the intermediate input price index. To simplify the equation, we assume that foreign firms pay a fixed cost with resources from the parent company.
} 
eliminated, and our estimating equation becomes

$$
\begin{aligned}
\Delta n_{p, t}^{i}= & \gamma_{0}+\gamma_{1} \Delta \ln w_{p, t}+\gamma_{2} \Delta \ln r_{p, t}+\gamma_{3} \Delta \ln P_{p, t}^{u} \\
& +\gamma_{4} \Delta \ln \left\{\sum_{l=1}^{P+W}\left(t_{p l, t}^{i}\right)^{1-\sigma^{i}} E_{l, t}^{i}\left(P_{l, t}^{i}\right)^{\sigma^{i}-1}\right\} .
\end{aligned}
$$

Thus in our empirical analysis we include average wages varying by province and time. The theory predicts a negative coefficient on wages, that is other things equal, firms prefer to locate in provinces that offer lower wages. As in the model, we assume that new entrants are too small individually to influence the provincial wage, so they take it as given. We also assume that the supply of workers in each province is given and workers are immobile between provinces and mobile between industries within a province. Thus in effect, we are treating each province analogously to a country in the theoretical model. This assumption is a reasonable approximation in China, given the hukou system. ${ }^{8}$ The other province specific $\operatorname{costs} r_{p}$ could include any other factors of production whose costs vary across provinces, for example electricity prices. Transport costs are modelled as a function of distance. Transport costs can also be affected by the availability of infrastructure, such as the number of sea berths, river berths and lengths of railroads, which we include separately.

Our key variables of interest are market and supply access variables. We hypothesize that profits are positively related to better access to intermediate inputs, which are reflected in a lower intermediate input price index, $P_{p}^{u}$, which we will proxy by three different supplier access variables; and that firms are also concerned about good market access, reflected in the last term, which we will proxy by various market access variables. We define these variables

\footnotetext{
${ }^{8}$ The hukou is a system of residence permits that regulates the movement of labor.
} 
in the next section.

\section{Data and Measurement}

\subsection{NBS Data}

The data used in the analysis have been collected by the China National Bureau of Statistics (NBS) at the firm level and then aggregated up to 600 industries by province, based on the 4 digit Chinese Industrial Classification. Before releasing this data to us, the NBS removed all 'sensitive industries' from the sample, and then we excluded agriculture, extractive industries and services in order to focus on the manufacturing sector. The information available includes the number of foreign firms, the value of output of foreign firms and the value of output of domestic firms. All variables vary by province, sector and time. Our sample covers the 1998-2001 period. It was not possible to include earlier years in the sample as data on the number of foreign firms were unavailable.

The figures indicate that a vast majority of foreign entry in 2001 occurred in coastal provinces (see Appendix). Seven out of twelve provinces in the coastal region saw the number of foreign investment projects rising by more than a hundred. Guangdong and Zhejiang were the most successful provinces increasing the number of foreign investment enterprises (FIEs) by about 600 each. Although midland provinces received much less net foreign investment, some provinces like Hunan recorded a net entry as high as 40, similar to some of the coastal provinces such as Beijing.

In terms of distribution of net entry across industries, both sectors producing consumer goods and industrial parts and components appeared to be attractive to foreign investors. 
The more attractive consumer industries included paper products, household plastic products, lamps and lanterns, and cotton knitting, while in the industrial categories there was a lot of foreign activity in electronic elements and automobile fittings and parts. In 2000 and 2001, manufacturing of clothing (classification 1810) experienced the largest rise in the number of foreign projects, from 160 to 260 . See Table 1A for details.

Foreign investment enterprises account for a significant share of industrial output produced in China. In 2001 their share in total production was equal to 31.3 percent. The share of FIEs in provincial output ranged from 2.4 percent in Xinjiang to 58 percent in Tianjin, 65 in Fujian and 61 in Guangdong in 2001. In twenty sectors (out of 515 considered in our sample), foreign enterprises accounted for three-quarters or more of industrial output produced in China in 2001. These included some technology intensive industries, such as manufacturing of copying machines, computers, cameras and instruments, communication equipment, radio and tape recorders, integrated circuits as well as consumer good industries - processing of fish sauce and production of soft drinks.

\subsection{Entry and Exit of Foreign Firms}

The dependent variable in our model is defined as the change in the number of foreign firms operating in industry $i$, province $p$, at time $t$, or in other words the net entry of foreign firms: $\Delta n_{p, t}^{i}=n_{p, t}^{i}-n_{p, t-1}^{i}$. The variable is positive if the number of firms that entered is greater than the number of firms that exited; zero if there has been no change or the number of new firms exactly equals the number of exiting firms; and negative if the number of exiting firms exceeded the number of new entrants. ${ }^{9}$

\footnotetext{
${ }^{9} 20 \%$ of the observations are non-zero.
} 


\subsection{Supplier Access}

We construct three measures of supplier access. The first one is $S A_{-} o w n_{p, t}^{i}$ which captures the availability of inputs used by industry $i$ in province $p$ where it is operating:

$$
S A_{-} o w n_{p, t}^{i}=\sum_{k=1}^{K} a_{i k} \frac{Y_{p, t}^{k}}{Y_{C H I N A, t}^{k}} * D I S T_{p p}^{-1},
$$

where $Y_{p, t}^{k}$ is the output of industry $k$ produced in province $p$ at time $t$. It is divided by the total output of industry $k$ produced in China, to get the share of output of each industry $k$ produced in each province. Since industries use more than one intermediate input, these output shares are weighted by $a_{i k}$, which are the coefficients from the China national inputoutput (I/O) table for 1997. Given that this is the most recent I/O table available, we assumed that the technology is constant throughout the sample period. There is variation in the supplier access variables due to entry and exit of firms. There are 70 manufacturing I/O codes, which we concord with the industrial data. Thus, while we analyze entry for 515 industries, our proxies for supplier access are defined for $70 \mathrm{I} / \mathrm{O}$ codes. In order to make this variable comparable with the proxy for input availability in other provinces $\left(S A_{-}\right.$outer $\left.{ }_{p, t}^{i}\right)$ we adjust it for the within province distance, which is defined as $D I S T_{p p}=\sqrt{\frac{\text { Area }}{\pi}}$.

The availability of intermediate inputs in the rest of China is proxied by

$$
S A_{-} \text {outer }_{p, t}^{i}=\sum_{k=1}^{K} a_{i k} \sum_{l \neq p}^{P} \frac{Y_{l, t}^{k}}{Y_{C H I N A, t}^{k}} * D I S T_{l p}^{-1}
$$

which is analogous to the own province supplier access measure. To take account of the additional cost of accessing inputs from other provinces, we weight the output shares produced in each province by the inverse of distance from province $p$ to province $l$. While this 
measure is intended to capture the cost of transporting intermediate inputs it may also, to some extent, reflect local protectionism.

The importance of intermediate supplies from the rest of the world is proxied by trade weighted tariffs imposed by China on imported intermediate inputs, weighted by the I/O coefficient $a_{i k}$, to reflect the fact that the relative importance of inputs varies by industry,

$$
S A_{-} \operatorname{abroad}_{t}^{i}=\sum_{k=1}^{K} a_{i k} * \operatorname{tariff} s_{t}^{k}
$$

The information on trade weighted tariffs on products corresponding to the I/O codes comes from the World Bank's WITS database. It should be noted that many industries in China have access to duty free intermediate inputs through duty drawbacks and hence would not be affected by tariffs on intermediate inputs. Nonetheless, there are many industries that do pay these tariffs and thus it is important to include this variable in the estimation. ${ }^{10}$

\subsection{Market Access}

We construct two measures of market access to reflect that firms can supply other firms and households within their own province and in other provinces. The own market access measure is defined as

$$
M A_{-} o w n_{p, t}^{i}=\left[\sum_{k=1}^{K} b_{i k} \frac{Y_{p, t}^{k}}{Y_{C H I N A, t}^{k}}+b_{i} \frac{G D P_{p, t}}{G D P_{C H I N A, t}}\right] * D I S T_{p p}^{-1},
$$

where $Y_{p, t}^{k}$ is the output of industry $k$ produced in province $p$ at time $t$. It is divided by the total output of industry $k$ produced in China, to get the share of industry $k$ 's output produced in each province. The share is then weighted by $b_{i k}$, which is the fraction of

\footnotetext{
${ }^{10}$ Approximately 40 per cent of imports are subject to tariffs.
} 
industry $i$ 's output sold to industry $k$ as intermediate input, and $b_{i}$ is the fraction sold for final consumption to households. Note that $\sum_{k=1}^{K} b_{i k}+b_{i}=1$. The coefficients $b_{i k}$ and $b_{i}$ have been calculated based on the China national I/O table for 1997.

Similarly, market access to the rest of China is defined as

$$
M A_{-} \text {outer }_{p, t}^{i}=\sum_{k=1}^{K} b_{i k} \sum_{l \neq p}^{P} \frac{Y_{l, t}^{k}}{Y_{C H I N A, t}^{k}} * D I S T_{l p}^{-1}+b_{i} \sum_{l \neq p}^{P} \frac{G D P_{l, t}}{G D P_{C H I N A, t}} * D I S T_{l p}^{-1},
$$

where each province's consumption of industry's $i$ 's output is weighted by the inverse of distance.

\subsection{Provincial characteristics}

In addition to distance as a proxy for trade costs, we include in the estimation the number of river and sea berths and length of railroads, using information from the China Annual Statistical Yearbooks. The degree of openness of a province is constructed from international trade data from the Chinese Customs Office. The production cost variables at the provincial level include data on electricity prices and wages obtained from the NBS. Wages are calculated as the ratio of the total wage bill to employment by province and year. We include all locations in China except Tibet and Inner Mongolia because the latter two have very little industrial activity. This gives us 29 locations comprising 25 provinces and 4 directly administered cities: Shanghai, Beijing, Tianjin and Chongqing. Table 1 provides summary statistics of all the variables. 


\subsection{Model Specification}

Substituting in the proxies for supplier and market access, our estimating equation (2.11) can be rewritten as

$$
\begin{aligned}
& \Delta n_{p, t}^{i,}=\alpha+\beta_{S A} \ln \frac{\left(S A_{-} \text {own } n_{p, t}^{i}+\beta_{S A_{-} \text {outer }} S A_{-} \text {outer } r_{p, t}^{i}\right)}{\left(S A_{-} \text {own } n_{p, t-1}^{i}+\beta_{S A_{-} \text {outer }} S A_{-} \text {outer } r_{p, t-1}^{i}\right)}
\end{aligned}
$$

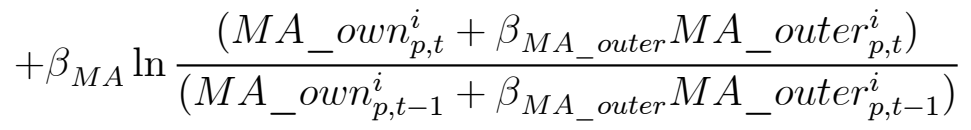

$$
\begin{aligned}
& +\beta_{S A \_a b r o a d} \Delta \ln S A \_a b r o a d d_{p, t}^{i}+\Delta \ln X_{p, t} \beta+\varepsilon_{p, t}^{i} \text {. }
\end{aligned}
$$

We estimate equation (3.6) using ordinary least squares (ols), omitting the outer terms, and with non-linear least squares (nls), adjusting standard errors for clustering on I/O-code-year combinations. Since market access and supplier access variables tend to be highly correlated, in addition to the full specification presented above we also estimate models with only market access or supplier access variables.

\section{Results}

The results, presented in Table 2 , confirm the importance of proximity to markets and suppliers. We present both ols and nls results in all the Tables to illustrate the importance of links to other provinces. ${ }^{11}$ Comparing the ols results in columns (1) to (3) to the nls results in columns (4) to (6), we see that the magnitudes of the coefficients on market access and supplier access variables are much higher in the nls estimations, where we take account

\footnotetext{
${ }^{11}$ This also serves as an additional robustness test - the fact that coefficients on all the other variables are similiar in both specifications adds confidence that the non-linear estimations are in fact global minima rather than local ones.
} 
of access to other provinces. Comparing columns (1) and (4), where both market access and supplier access are included, the coefficient on $M A$ increases from 0.16 to 1.14 , and the coefficient on $S A$ increases from 0.26 to 1.09 , which suggests that access to other provinces is important for entry. Note that even though some of the access variables are individually insignificant in column (4), F-tests indicate they are jointly significant with a $p$-value equal to 0 . In columns (5) and (6), we re-estimate the equation with only SA in column (5) and only MA in column (6). Here we see that the coefficients on $S A$ and $M A$ are even larger than when they are included jointly, which is likely due to the correlation between the terms. Using estimates from column (4) with the full specification, the results indicate that a doubling of either market access or supplier access increases the entry of foreign firms by 0.8, and evaluated at the mean number of foreign firms (equal to 1.87), this is equivalent to a $40 \%$ increase in the number of foreign firms in an industry/province.

Interestingly, both the outer terms on market access and supplier access are positive and less then one. Since both own and outer supplier access have been adjusted for distance, the parameter $\beta_{S A_{-} \text {outer }}$ allows us to compare the relative magnitude of the two effects. A coefficient below one would suggest that the presence of suppliers in other provinces is less important that the ability to source within the own province. This indeed is the case as $\beta_{S A_{-} \text {outer }}$ equals 0.14 in column (4); and the coefficient on $\beta_{M A_{-} \text {outer }}$ is 0.42 , which implies that outer supplier access is approximately $14 \%$ of the total supplier access effect, and the outer market access effect is approximately 40 percent of the total market access effect. This finding suggests that firms may face some difficulties with accessing inputs and selling their products in neighboring provinces either due to high transport costs and/or interprovincial 
barriers to trade.

Since foreign investors may also import some of their inputs, the model controls for the average tariff charged on inputs used by industry $i$ and the province's openness to trade (defined as the share of provincial imports and exports to GDP). As hypothesized, the average tariff bears a negative sign, while openness to trade is positively correlated with foreign entry. Both variables are significant in all six specifications, which suggests that ease of access to imported intermediates is important to foreign investors.

Production costs are also crucial in determining where foreign firms locate. As anticipated, the coefficient on the average provincial wage is negative and significant suggesting that foreign investors are attracted to locations with lower labor costs. Further, provinces with cheaper electricity appear to be more attractive as an investment destination. In all specifications in Table 2, the coefficient on wage is equal to -0.6 and on electricity around -0.45. Thus a doubling of production costs decreases foreign entry between $17 \%$ and $22 \%$, respectively. This is about half the size of the effect of doubling either $M A$ or $S A$.

The availability of infrastructure plays a role in the entry decision as well. The higher the number of sea berths or the length of railroads the higher the foreign entry. The number of river berths, on the other hand, appears to have a very small negative effect. The length of rail has the largest effect out of the infrastructure variables, with a coefficient equal to 0.85 . This implies that doubling rail increases foreign entry by $32 \%$, suggesting that transport costs are indeed a significant factor in determining entry. 


\subsection{Sensitivity}

Links to Domestic Firms To ensure that the output of the new entrants is not driving the results, we reconstruct the $M A$ and $S A$ variables using only the output of domestic firms. Ideally, we would only purge the variables of the output of those new foreign entrants, however, since our data are at the industry level this information is not available. One drawback of removing all foreign output in the access variables is that it may be omitting important inter-industry linkages in industries that may be dominated by foreign firms. The results are presented in Table 3 . We see that the inclusion of these domestic oriented linkage terms increases the size of the SA variables and reduces the size of the MA variables. The coefficients on all other variables are very similar to the earlier estimates. In this case, it appears that the high correlation between $M A$ and $S A$ variables may be affecting the $M A$ coefficients when all of them are included, as the hypothesis that $\beta_{M A_{-} \text {own }}=\beta_{M A_{-} \text {outer }}=0$ cannot be rejected in column (4). Yet the F-test of the joint significance of the $M A$ terms when they are included on their own as in column (6) indicates joint significance with a $p$-value equal to 0 . The two $S A$ coefficients have a higher magnitude than before with both terms being statistically significant in column (5), which suggests that access to inputs purchased from domestic firms is relatively more important than those purchased from other foreign firms.

Domestic Oriented Foreign Firms The ability to sell products within China is likely to matter less for export-oriented investors. Thus, to check the robustness of our earlier findings we re-estimate the above models restricting the sample to industry-province-year 
combinations where less than 30 percent of output is exported (see Table 4). The exportorientation of a given industry in a particular province is calculated by summing the value of exports of all firms operating in a given industry, province and year combination and dividing it by the sum of the total production in the same cell. If an observation for a particular year is missing it is substituted with an observation for the closest year available. ${ }^{12}$ The results confirm our earlier findings. The effects of the $M A$ and $S A$ variables are of similar magnitudes to the previous results. Although the coefficients are a bit smaller than in the full sample, they range between 0.6 and 0.7 , as compared to 1.1 in Table 2 , they correspond to a similar sized effect when evaluated at the mean number of firms: doubling $S A$ is associated with a $51 \%$ increase in entry when evaluated at the mean number of foreign firms which is equal to one in this sub-sample, and doubling $M A$ is associated with a $44 \%$ increase.

The signs and significance levels of other variables remain unchanged. To ensure that our results are not driven by choosing the cutoff at 30 percent, we also estimate the model for industry-province-year combinations where the share of exported output is less than 50 percent. The conclusions with respect to our key variables remain unchanged.

\subsection{Extensions}

In Table 5, we explore the effect of additional controls for distance to port ${ }^{13}$ and the investment climate in the province, proxied by the total number of foreign firms in the province lagged one period. The results suggest that provinces close to ports appear to be more at-

\footnotetext{
${ }^{12}$ This data series has been provided by Sourafel Girma. See Girma and Gong (2004) for detailed information on the data source.

${ }^{13}$ This is measured as the shortest distance to one of the three major ports: Shanghai, Hong Kong and Qinhuangdao (Hebei).
} 
tractive investment destinations, which is not surprising, since as we discussed earlier, coastal regions have been the primary recipients of FDI in China. The negative coefficient in this first differenced equation suggests that distance to ports has become more important over time.

The 'total foreign firms' variable is defined as the total number of foreign firms in all industries in a province, rather than a particular industry as is the case with the dependent variable, and it enters as a one period lag. The coefficient is positive and significant. Provinces with a large number of foreign firms are more attractive to new entrants either due to agglomeration benefits or due to a better investment climate that attracted the other firms. It seems that the competition for resources or congestion externalities have not yet outweighed the benefits of being in a province with many other foreign firms present. Controlling for distance to ports and the lagged number of foreign firms reduces the market access effects slightly but leaves the supplier access coefficients unchanged.

\section{Conclusion}

This study examines factors driving entry of foreign firms in China, using a comprehensive dataset covering nearly all manufacturing industries at the provincial level during the period 1998-2001. The analysis is based on a new economic geography model, and thus focuses on the importance of market and supplier access effects both within and outside the province of entry, relative to production costs.

The findings suggest that access to customers and suppliers of intermediate inputs are the key determinants of FDI inflows. The analysis also highlights the importance of taking 
into account linkages to neighboring regions. After allowing for such linkages, the effects of market and supplier access increase significantly. The results show that doubling either market access or supplier access is associated with a $40 \%$ increase in the entry of foreign firms, whereas the effect of doubling production costs reduces entry of foreign firms by roughly $20 \%$.

The analysis also shows that the presence of customers and suppliers in the province of entry matters much more than market and supplier access to the rest of China. This may be due to the underdeveloped transport infrastructure and informal barriers to trade and is consistent with the fragmentation of the Chinese market.

Other trade costs also appear to play an important role in attracting FDI. For instance, the availability of infrastructure, such as rail lines, is positively correlated with foreign entry, whereas high tariffs on imported inputs deter entry. Provinces which are more open to foreign trade attract more foreign firms. In sum, barriers to trade whether in the form on tariffs on imported inputs, informal barriers to inter-provincial trade or underdeveloped infrastructure play a significant role in the decisions of foreign investors contemplating entry into China.

If China's central government is serious about redressing regional inequality, it must address the issue of local protection and high internal trade costs. Dismantling inter-provincial barriers, and improving transport infrastructure will increase market and supplier access for both Chinese and foreign producers, attracting entry of new firms. 


\section{References}

[1] Amiti, Mary (2005). Location of Vertically Linked Industries: Agglomeration versus Comparative Advantage. European Economic Review, forthcoming.

[2] Amiti, Mary and Mei Wen (2001). Spatial Distribution of Manufacturing in China, in (eds.) P.J. Lloyd and X.G. Zhang, Modelling the Chinese Economy, Edward Elgar.

[3] Bai, Chong-En, Yingjuan Du, Zhigang Tao and Sarah Y. Tong (2004). Local Protection and Regional Specialization: Evidence from China's Industries. Journal of International Economics, 63, 397-417.

[4] Caves, Richard E. (1982). Multinational Enterprise and Economic Analysis. Cambridge University Press: New York.

[5] Cheng, Leonard K. and Yum K. Kwan (2000). What are the determinants of the location of foreign direct investment? The Chinese experience. Journal of International Economics, 51, 379-400.

[6] Dean, Judith M., Mary E. Lovely, Hua Wang (2002). Foreign Direct Investment and Pollution Havens: Evaluating the Evidence from China, mimeo, US International Trade Commission, Washington, DC.

[7] Desai, Mihir A., Fritz C. Foley and James R. Hines, Jr. (2004). Foreign Direct Investment in a World of Multiple Taxes. Journal of Public Economics 88, 2727-44. 
[8] Girma, Sourafel and Yundan Gong (2004). Are There FDI-generated Externalities to Chinese State-owned Enterprises? mimeo, University of Leicester.

[9] Head, Keith and John Ries (1996). Inter-City Competition for Foreign Investment: Static and Dynamic Effects of China's Incentive Areas. Journal of Urban Economics, $40,38-60$.

[10] Head, Keith and Thierry Mayer (2004). Market Potential and the Location of Japanese Investment in the European Union. Review of Economics and Statistics, 86.

[11] Huang, Lin and Shang-Jin Wei (2002). One China, Many Kingdoms? Using Individual Product Prices to Understand Local Protectionism in China, mimeo, International Monetary Fund, Washington, DC.

[12] Javorcik, Beata S. (2004). Does Foreign Direct Investment Increase the Productivity of Domestic Firms? In Search of Spillovers through Backward Linkages, American Economic Review, 93, 605-627.

[13] Krugman, Paul and Anthony J. Venables (1995). Globalization and the Inequality of Nations. Quarterly Journal of Economics, 110, 857-880.

[14] Kumar, Anjali (1994). China: Internal Market Development and Regulation. World Bank Country Study, Washington DC: World Bank.

[15] Markusen, James R., 1995, The Boundaries of Multinational Enterprises and the Theory of International Trade, Journal of Economic Perspectives 9(2), 169-189. 
[16] Markusen, James R. and Anthony J. Venables (2000), The Theory of Endowment, Intraindustry and Multinational Trade, Journal of International Economics 52, 209-234.

[17] Markusen, James R. and Anthony J. Venables (1998), Multinational Firms and New Trade Theory, Journal of International Economics 46, 183-203.

[18] Naughton, Barry (1999). How Much Can Regional Integration Do to Unify China's Market? mimeo, University of California San Diego.

[19] Poncet, Sandra (2003). Measuring Chinese Domestic and International Integration. China Economic Review 14, 1-21.

[20] Young, Alwyn (2000). The Razor's Edge: Distortions and Incremental Reform in the People's Republic of China. Quarterly Journal of Economics, 115, 1091-1135.

[21] World Investment Report: Transnational Corporations and Export Competitiveness. (2002) New York : United Nations. 

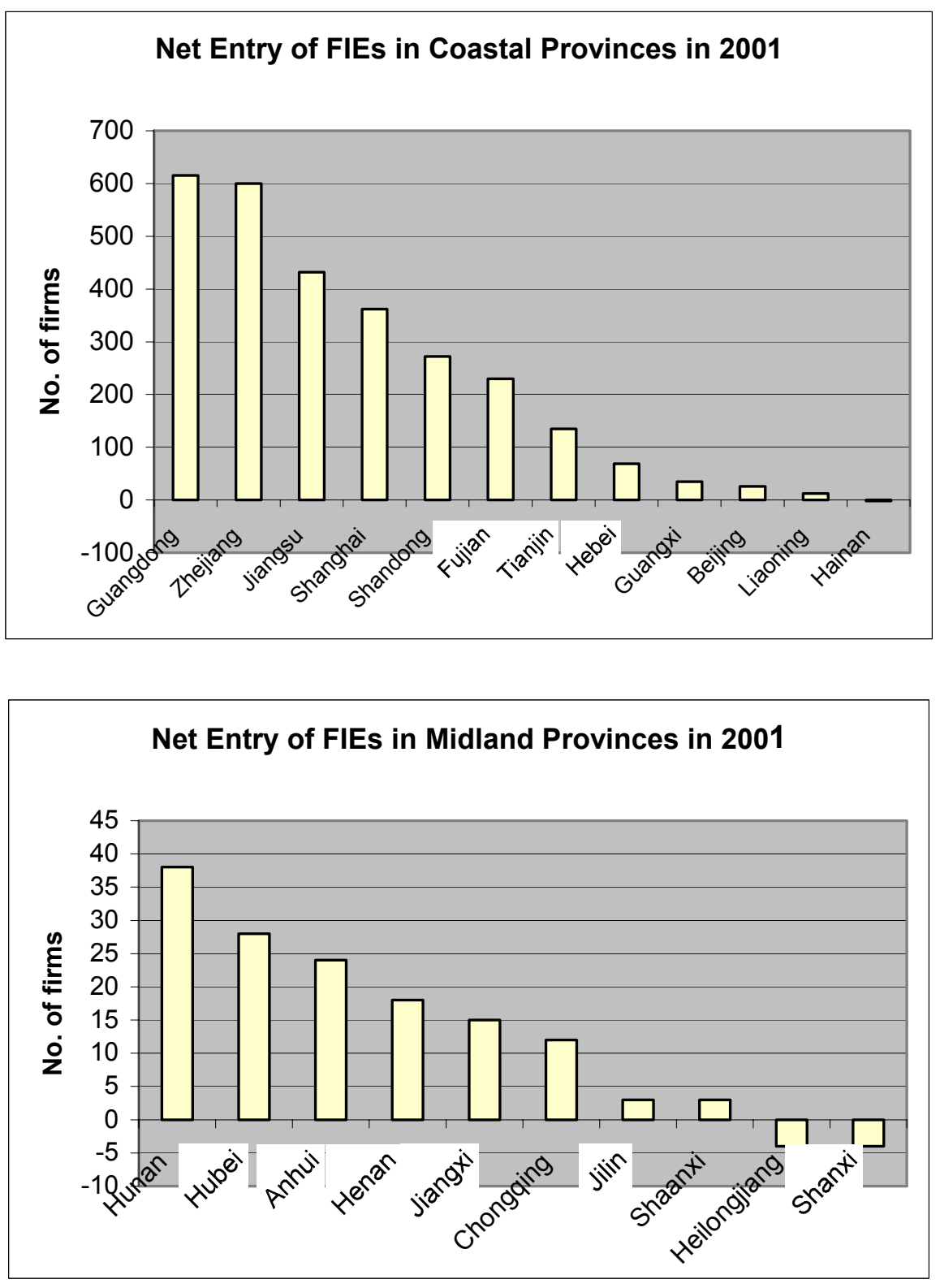


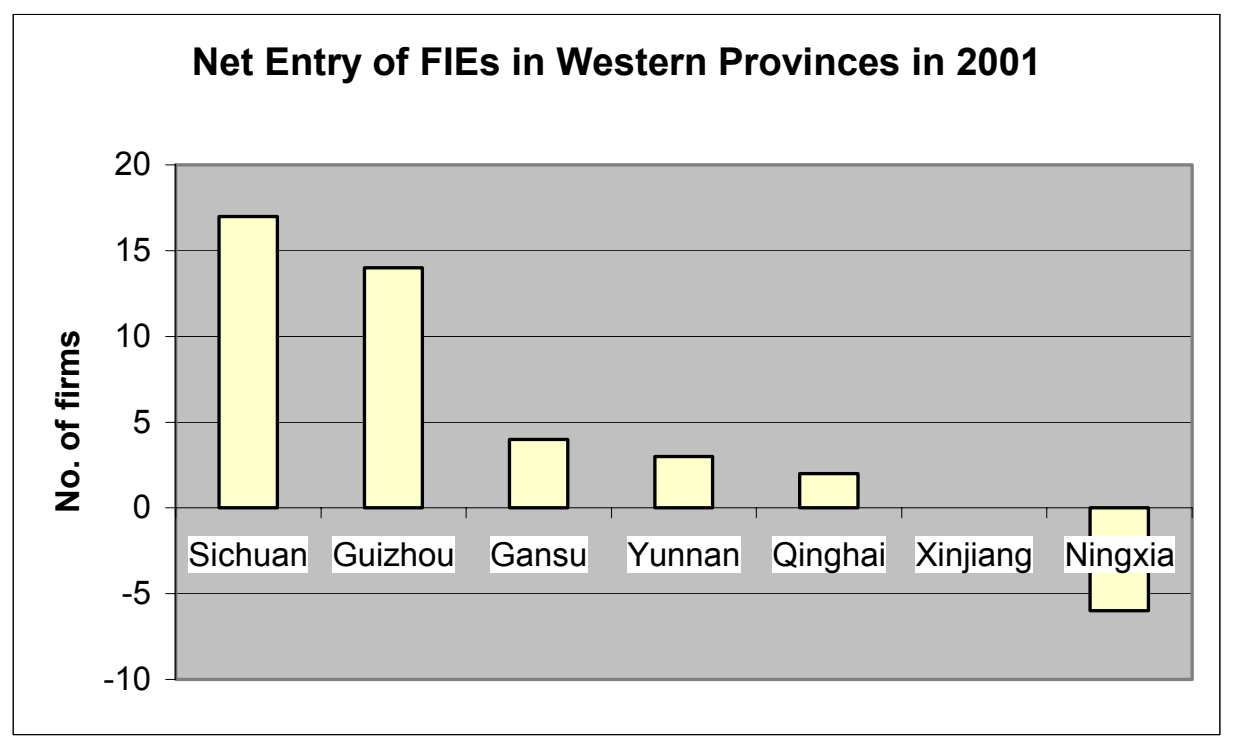

Table 1A. Industries with the Highest Net Entry of Foreign Investment Enterprises (FIEs)

\begin{tabular}{rrrlr}
\hline \multicolumn{1}{c}{ Rank } & \multicolumn{2}{c}{ Year } & \multicolumn{1}{c}{ Industry code } & Net entry \\
\hline 1 & 2001 & 1810 & Manufacture of clothing & 260 \\
2 & 2000 & 1810 & Manufacture of clothing & 160 \\
3 & 2001 & 4160 & Manufacture of electronic elements & 131 \\
4 & 2000 & 4160 & Manufacture of electronic elements & 83 \\
5 & 2001 & 2230 & Manufacture of paper products & 79 \\
6 & 2001 & 3070 & Manufacture of household plastic products & 70 \\
7 & 2000 & 3727 & Manufacture of automobile fittings and parts & 69 \\
8 & 2001 & 3727 & Manufacture of automobile fittings and parts & 64 \\
9 & 2001 & 4073 & Manufacture of lamp and lanterns & 59 \\
10 & 2001 & 1781 & Manufacture of cotton knitting & 58 \\
11 & 1999 & 3090 & Manufacture of other plastic products & 51 \\
12 & 2001 & 1390 & Processing of other food & 48 \\
13 & 2001 & 1790 & Other textile industry & 48 \\
14 & 2001 & 3434 & Manufacture of abrasive tools & 48 \\
15 & 2001 & 2312 & Printing of packing, decorating & 47 \\
\hline
\end{tabular}


Table 1: Summary statistics (1999 to 2001)

\begin{tabular}{|c|c|c|c|c|c|}
\hline Variable & no. of obs & mean & std dev & $\min$ & $\max$ \\
\hline$(\mathrm{n})_{\mathrm{ipt}}$ & 44,805 & 1.87 & 12.01 & 0 & 922 \\
\hline$\Delta(\mathrm{n})_{\mathrm{ipt}}$ & 44,805 & 0.11 & 1.57 & -116 & 101 \\
\hline$(\text { MA_own })_{\text {ipt }}$ & 44,805 & 0.0002 & 0.0004 & 0.0000 & 0.0057 \\
\hline$\Delta \ln (\text { MA_own })_{\text {ipt }}$ & 44,805 & -0.0133 & 0.1125 & -2.7159 & 1.6639 \\
\hline$(\text { MA_own_domestic) })_{\text {ipt }}$ & 44,805 & 0.0002 & 0.0003 & 0.0000 & 0.0062 \\
\hline$\Delta \ln (\text { MA_own_domestic })_{\mathrm{ipt}}$ & 44,805 & -0.0122 & 0.1239 & -2.8279 & 1.5531 \\
\hline$(\text { MA_outer })_{\text {ipt }}$ & 44,805 & 0.0011 & 0.0005 & 0.0001 & 0.0036 \\
\hline$\left(\mathrm{SA} \_ \text {own }\right)_{\mathrm{ipt}}$ & 44,805 & 0.0002 & 0.0004 & 0.0000 & 0.0031 \\
\hline$\Delta \ln (\text { SA_own })_{\text {ipt }}$ & 44,805 & -0.0182 & 0.1201 & -1.5659 & 1.5223 \\
\hline$(\text { SA_own_domestic) })_{\mathrm{ipt}}$ & 44,805 & 0.0002 & 0.0003 & 0.0000 & 0.0029 \\
\hline$\Delta \ln (\text { SA_own_domestic })_{\mathrm{ipt}}$ & 44,805 & -0.0170 & 0.1371 & -1.7373 & 1.6424 \\
\hline$(\text { SA_outer })_{\text {ipt }}$ & 44,805 & 0.0011 & 0.0005 & 0.0001 & 0.0043 \\
\hline $\ln (\text { SA_abroad })_{\mathrm{pt}}$ & 44,805 & 16.62 & 7.62 & 7.18 & 54.32 \\
\hline$\Delta \ln \left(\mathrm{SA} \_ \text {_abroad }\right)_{\mathrm{pt}}$ & 44,805 & -0.01 & 0.07 & -0.33 & 0.92 \\
\hline$(\text { wage })_{\mathrm{pt}}$ & 44,805 & 8.76 & 2.53 & 5.29 & 17.72 \\
\hline$\Delta \ln (\text { wage })_{\mathrm{pt}}$ & 44,805 & 0.12 & 0.10 & -0.06 & 0.85 \\
\hline$(\text { elect_price })_{\mathrm{pt}}$ & 44,805 & 0.43 & 0.08 & 0.34 & 0.65 \\
\hline$\Delta \ln (\text { elect_price })_{\mathrm{pt}}$ & 44,805 & 0.01 & 0.04 & -0.13 & 0.14 \\
\hline$(\text { population })_{\mathrm{pt}}$ (millions) & 44,805 & 41.80 & 25.30 & 4.82 & 92.60 \\
\hline$\Delta \ln (\text { population })_{\mathrm{pt}}$ & 44,805 & 0.00 & 0.04 & -0.07 & 0.21 \\
\hline$(\text { openness })_{\mathrm{pt}}$ & 44,805 & 0.25 & 0.31 & 0.04 & 1.50 \\
\hline$\Delta \ln (\text { openness })_{\mathrm{pt}}$ & 44,805 & 0.04 & 0.20 & -0.55 & 0.56 \\
\hline$(\text { seaberths })_{\mathrm{pt}}$ & 44,805 & 31.83 & 64.32 & 0 & 272 \\
\hline$\Delta(\text { seaberths })_{\mathrm{pt}}$ & 44,805 & 0.92 & 4.81 & -10 & 31 \\
\hline$(\text { riverberths })_{\mathrm{pt}}$ & 44,805 & 27.36 & 72.22 & 0 & 387 \\
\hline$\Delta$ (riverberths $)_{\mathrm{pt}}$ & 44,805 & -9.52 & 57.61 & -337 & 170 \\
\hline$(\text { rail })_{\mathrm{pt}}$ & 44,805 & 1960.63 & 1178.25 & 219 & 5503.2 \\
\hline$\Delta \ln (\text { rail })_{\mathrm{pt}}$ & 44,805 & 0.07 & 0.15 & -0.20 & 1.02 \\
\hline $\ln (\text { Distance_port })_{\mathrm{pt}}$ & 44,805 & 6.37 & 1.06 & 2.98 & 9.1 \\
\hline $\ln (\text { Total foreign firms })_{\mathrm{p}, \mathrm{t}-1}$ & 44,805 & 5.61 & 1.63 & 1.79 & 9.00 \\
\hline
\end{tabular}


Table 2: Determinants of Foreign Entry

\begin{tabular}{|c|c|c|c|c|c|c|}
\hline \multicolumn{7}{|c|}{ Dependent Variable: $\Delta(\mathrm{n})_{\mathrm{ipt}}$} \\
\hline & (1) & (2) & (3) & (4) & (5) & (6) \\
\hline & ols & ols & ols & nls & nls & nls \\
\hline \multirow[t]{2}{*}{$\Delta \ln (\text { MA_own })_{\text {ipt }}$} & $0.159^{* *}$ & & $0.258 * * *$ & 1.144 & & $1.774 * * *$ \\
\hline & $(0.072)$ & & $(0.082)$ & $(0.865)$ & & $(0.752)$ \\
\hline \multirow[t]{2}{*}{$(\text { MA_outer })_{\mathrm{ipt}}{ }^{\mathrm{c}}$} & & & & 0.424 & & 0.356 \\
\hline & & & & $(0.477)$ & & $(0.249)$ \\
\hline \multirow[t]{2}{*}{$\Delta \ln (\text { SA_own })_{\text {ipt }}$} & $0.269 * * *$ & $0.321 * * *$ & & $1.094^{* *}$ & $1.463 * * *$ & \\
\hline & $(0.054)$ & $(0.054)$ & & $(0.553)$ & $(0.539)$ & \\
\hline \multirow[t]{2}{*}{$\left(\mathrm{SA} \_ \text {outer }\right)_{\mathrm{ipt}}^{\mathrm{c}}$} & & & & 0.142 & $0.168^{*}$ & \\
\hline & & & & $(0.113)$ & $(0.095)$ & \\
\hline \multirow{2}{*}{$\Delta \ln (\text { SA_abroad })_{\mathrm{pt}}$} & $-0.353 * *$ & $-0.354 * *$ & $-0.360 * *$ & $-0.364 * * *$ & $-0.364 * * *$ & $-0.364 * * *$ \\
\hline & $(0.143)$ & $(0.145)$ & $(0.139)$ & $(0.140)$ & $(0.141)$ & $(0.139)$ \\
\hline \multirow{2}{*}{$\Delta \ln (\text { wage })_{\mathrm{pt}}$} & $-0.595 * * *$ & $-0.596^{* * *}$ & $-0.603 * * *$ & $-0.602 * * *$ & $-0.603 * * *$ & $-0.605^{* * *}$ \\
\hline & (0.097) & $(0.097)$ & $(0.098)$ & $(0.097)$ & $(0.097)$ & (0.097) \\
\hline \multirow[t]{2}{*}{$\Delta \ln (\text { elect_price })_{\mathrm{pt}}$} & $-0.473 * *$ & $-0.489 * * *$ & $-0.463 * *$ & $-0.419 * *$ & $-0.432 * * *$ & $-0.447 * * *$ \\
\hline & $(0.185)$ & $(0.184)$ & $(0.187)$ & $(0.182)$ & $(0.182)$ & $(0.185)$ \\
\hline \multirow[t]{2}{*}{$\Delta \ln (\text { population })_{\mathrm{pt}}$} & $1.271 * * *$ & $1.292 * * *$ & $1.285^{* * *}$ & $1.376^{* * *}$ & $1.376^{* * *}$ & $1.349 * * *$ \\
\hline & $(0.353)$ & (0.354) & (0.354) & $(0.355)$ & $(0.356)$ & $(0.356)$ \\
\hline \multirow[t]{2}{*}{$\Delta \ln (\text { openness })_{\mathrm{pt}}$} & $0.182 * * *$ & $0.180 * * *$ & $0.180 * * *$ & $0.176 * * *$ & $0.176^{* * *}$ & $0.176^{* * *}$ \\
\hline & $(0.067)$ & $(0.067)$ & $(0.066)$ & $(0.066)$ & $(0.066)$ & $(0.066)$ \\
\hline \multirow[t]{2}{*}{$\Delta \ln (\text { seaberths })_{\mathrm{pt}}$} & $0.010 * * *$ & $0.010 * * *$ & $0.010 * * *$ & $0.010 * * *$ & $0.010 * * *$ & $0.010 * * *$ \\
\hline & $(0.003)$ & $(0.003)$ & $(0.003)$ & $(0.003)$ & $(0.003)$ & $(0.003)$ \\
\hline \multirow[t]{2}{*}{$\Delta \ln (\text { riverberths })_{\mathrm{pt}}$} & $-0.0002 * *$ & $-0.0002 *$ & $-0.0002 *$ & $-0.0003 * *$ & $-0.0002 * *$ & $-0.0002 *$ \\
\hline & $(0.0001)$ & $(0.0001)$ & $(0.0001)$ & $(0.0001)$ & $(0.0001)$ & $(0.0001)$ \\
\hline \multirow[t]{2}{*}{$\Delta \ln (\text { rail })_{\mathrm{pt}}$} & $0.852 * * *$ & $0.853 * * *$ & $0.851 * * *$ & $0.848 * * *$ & $0.852 * * *$ & $0.846^{* * *}$ \\
\hline & $(0.178)$ & $(0.178)$ & $(0.178)$ & $(0.177)$ & $(0.177)$ & $(0.178)$ \\
\hline \multirow{2}{*}{\multicolumn{2}{|c|}{$\mathrm{H}_{0}: \beta_{\mathrm{MA} \_ \text {outer }}=0 ; \beta_{\mathrm{SA} \_ \text {outer }}=0$}} & & & $\mathrm{~F}=18.73$ & & \\
\hline & & & & $p$-value $=0$ & & \\
\hline \multirow{2}{*}{\multicolumn{2}{|c|}{$\mathrm{H}_{0}: \beta_{\text {MA_own }}=0 ; \beta_{\text {MA_outer }}=0$}} & & & $\mathrm{~F}=5.53$ & & \\
\hline & & & & $p$-value $=0$ & & \\
\hline \multirow{2}{*}{\multicolumn{2}{|c|}{$\mathrm{H}_{0}: \beta \mathrm{S}_{\mathrm{A}_{-} \text {own }}=0 ; \beta \mathrm{S}_{\mathrm{A}_{-} \text {outer }}=0$}} & & & $\mathrm{~F}=15.42$ & & \\
\hline & & & & $p$-value $=0$ & & \\
\hline RSS & 108778.96 & 108791.50 & 108819.98 & 108688.05 & 108714.87 & 108762.89 \\
\hline Observations & 44805 & 44805 & 44805 & 44805 & 44805 & 44805 \\
\hline
\end{tabular}

Notes: a) ${ }^{*}$ significant at $10 \%$; $* *$ significant at $5 \% ; * * *$ significant at $1 \% ; b$ ) Robust standard errors corrected for clustering in parentheses; c) MA_outer and SAouter terms enter non-linearly as in equation (3.6). 
Table 3: Links to Domestic Firms

\begin{tabular}{|c|c|c|c|c|c|c|}
\hline \multicolumn{7}{|c|}{ Dependent Variable: $\Delta(\mathrm{n})_{\mathrm{ipt}}$} \\
\hline & (1) & (2) & (3) & (4) & (5) & (6) \\
\hline & ols & ols & ols & nls & nls & nls \\
\hline \multirow{2}{*}{$\Delta \ln (\text { MA_own })_{\text {ipt }}$} & 0.072 & & $0.139^{* *}$ & 0.1071 & & 0.7878 \\
\hline & $(0.046)$ & & $(0.055)$ & $(0.771)$ & & $(0.513)$ \\
\hline \multirow{2}{*}{$(\text { MA_outer })_{\mathrm{ipt}}^{\mathrm{c}}$} & & & & 0.780 & & 0.315 \\
\hline & & & & $(7.364)$ & & $(0.304)$ \\
\hline \multirow[t]{2}{*}{$\Delta \ln (\text { SA_own })_{\text {ipt }}$} & $0.167 * * *$ & $0.191 * * *$ & & 1.414 & $1.451^{* *}$ & \\
\hline & $(0.056)$ & $(0.058)$ & & $(0.881)$ & $(0.679)$ & \\
\hline \multirow[t]{2}{*}{$\left(\mathrm{SA} \_ \text {outer }\right)_{\mathrm{ipt}}^{\mathrm{c}}$} & & & & 0.4648 & $0.4672^{*}$ & \\
\hline & & & & $(0.341)$ & $(0.273)$ & \\
\hline \multirow[t]{2}{*}{$\Delta \ln (\text { SA_abroad })_{\mathrm{pt}}$} & $-0.358 * *$ & $-0.359 * *$ & $-0.361 * *$ & $-0.367 * * *$ & $-0.367 * * *$ & $\begin{array}{r}-0.365 * * * \\
(0.139)\end{array}$ \\
\hline & $\begin{array}{r}(0.143) \\
506 * * *\end{array}$ & $\begin{array}{r}(0.144) \\
506 * * *\end{array}$ & $\begin{array}{r}(0.140) \\
-0604 * * *\end{array}$ & $(0.141)$ & $\begin{array}{r}(0.141) \\
0.01 * * *\end{array}$ & $\begin{array}{r}(0.139) \\
-0.605 * * *\end{array}$ \\
\hline$\Delta \ln (\text { wage })_{\mathrm{pt}}$ & $\begin{array}{r}-0.596 * * * \\
(0.096)\end{array}$ & $\begin{array}{r}-0.596^{* * * *} \\
(0.096)\end{array}$ & $\begin{array}{r}-0.604 * * * \\
(0.098)\end{array}$ & $\begin{array}{r}-0.601 * * * \\
(0.098)\end{array}$ & $\begin{array}{r}-0.601 * * * \\
(0.097)\end{array}$ & $\begin{array}{r}-0.605 * * * \\
(0.097)\end{array}$ \\
\hline \multirow{2}{*}{$\Delta \ln (\text { elect_price })_{\mathrm{pt}}$} & $-0.476^{* *}$ & $-0.485^{* * *}$ & $-0.470 * *$ & $-0.430 * * *$ & $-0.431 * * *$ & $-0.456^{* * *}$ \\
\hline & $(0.186)$ & $(0.186)$ & $(0.187)$ & $(0.183)$ & $(0.184)$ & $(0.185)$ \\
\hline \multirow[t]{2}{*}{$\Delta \ln (\text { population })_{\mathrm{pt}}$} & $1.309 * * *$ & $1.316^{* * *}$ & $1.312 * * *$ & $1.389 * * *$ & $1.388 * * *$ & $1.353 * * *$ \\
\hline & $(0.353)$ & $(0.353)$ & $(0.355)$ & $(0.356)$ & $(0.355)$ & $(0.358)$ \\
\hline \multirow[t]{2}{*}{$\Delta \ln (\text { openness })_{\mathrm{pt}}$} & $0.179 * * *$ & $0.178 * * *$ & $0.178 * * *$ & $0.181 * * *$ & $0.180^{* * *}$ & $0.177 * * *$ \\
\hline & $(0.067)$ & $(0.067)$ & $(0.066)$ & $(0.067)$ & $(0.067)$ & $(0.066)$ \\
\hline \multirow{2}{*}{$\Delta \ln (\text { seaberths })_{\mathrm{pt}}$} & $0.011 * * *$ & $0.011 * * *$ & $0.011 * * *$ & $0.011 * * *$ & $0.011 * * *$ & $0.011 * * *$ \\
\hline & $(0.003)$ & $(0.003)$ & $(0.003)$ & $(0.003)$ & $(0.003)$ & $(0.003)$ \\
\hline \multirow[t]{2}{*}{$\Delta \ln (\text { riverberths })_{\mathrm{pt}}$} & $-0.0002 *$ & $-0.0002 *$ & $-0.0002 *$ & $-0.0002 *$ & $-0.0002 *$ & $-0.0002 *$ \\
\hline & $(0.0001)$ & $(0.0001)$ & $(0.0001)$ & $(0.0001)$ & $(0.0001)$ & $(0.0001)$ \\
\hline \multirow[t]{2}{*}{$\Delta \ln (\text { rail })_{\mathrm{pt}}$} & $0.858 * * *$ & $0.857 * * *$ & $0.856 * * *$ & $0.858 * * *$ & $0.858 * * *$ & $0.855^{* * *}$ \\
\hline & $(0.178)$ & $(0.178)$ & $(0.178)$ & $(0.177)$ & $(0.177)$ & $(0.178)$ \\
\hline \multirow{2}{*}{\multicolumn{2}{|c|}{$\mathrm{H}_{0}: \beta_{\text {MA_outer }}=0 ; \beta_{\text {SA_outer }}=0$}} & & & $\mathrm{~F}=11.82$ & & \\
\hline & & & & $p$-value $=0$ & & \\
\hline \multirow[t]{2}{*}{$\mathrm{H}_{0}: \beta_{\text {MA_own }}=0 ; \beta_{\text {MA_outer }}=0$} & & & & $\mathrm{~F}=0.05$ & & $\mathrm{~F}=6.53$ \\
\hline & & & & $p$-value $=0.96$ & & $p$-value $=0$ \\
\hline \multirow[t]{2}{*}{$\mathrm{H}_{0}: \beta \mathrm{S}_{\mathrm{A} \_ \text {own }}=0 ; \beta \mathrm{S}_{\mathrm{A}_{-} \text {outer }}=0$} & & & & $\mathrm{~F}=12.19$ & & \\
\hline & & & & $p$-value $=0$ & & \\
\hline RSS & 108823.92 & 108827.02 & 108844.30 & 108766.54 & 108766.76 & 108825.75 \\
\hline Observations & 44805 & 44805 & 44805 & 44805 & 44805 & 44805 \\
\hline
\end{tabular}

Notes: a)* significant at 10\%; ** significant at 5\%; *** significant at 1\%; b) Robust standard errors corrected for clustering in parentheses; c) MA_outer and SAouter terms enter non-linearly as in equation (3.6). 
Table 4: Domestic Market-oriented Foreign Firms

\begin{tabular}{|c|c|c|c|c|c|c|}
\hline \multicolumn{7}{|c|}{ Dependent Variable: $\Delta(\mathrm{n})_{\mathrm{ipt}}$} \\
\hline & (1) & (2) & (3) & (4) & (5) & (6) \\
\hline & ols & ols & ols & nls & nls & nls \\
\hline \multirow{2}{*}{$\Delta \ln (\text { MA_own })_{\text {ipt }}$} & $0.069 *$ & & $0.122 * * *$ & 0.640 & & $0.950 *$ \\
\hline & $(0.035)$ & & $(0.040)$ & $(0.585)$ & & $(0.521)$ \\
\hline \multirow[t]{2}{*}{$\left(\mathrm{MA} \_ \text {outer }\right)_{\mathrm{ipt}}^{\mathrm{c}}$} & & & & 0.915 & & 0.476 \\
\hline & & & & (1.116) & & $(0.388)$ \\
\hline \multirow[t]{2}{*}{$\Delta \ln (\text { SA_own })_{\text {ipt }}$} & $0.149 * * *$ & $0.171 * * *$ & & $0.732 *$ & $0.940^{* *}$ & \\
\hline & $(0.032)$ & $(0.031)$ & & $(0.412)$ & $(0.413)$ & \\
\hline \multirow[t]{2}{*}{$(\text { SA_outer })_{\mathrm{ipt}}{ }^{\mathrm{c}}$} & & & & 0.177 & 0.226 & \\
\hline & & & & $(0.144)$ & $(0.140)$ & \\
\hline \multirow[t]{2}{*}{$\Delta \ln (\text { SA_abroad })_{\mathrm{pt}}$} & $-0.117 *$ & $-0.118^{*}$ & $-0.122 * *$ & $-0.124 * *$ & $-0.124 * *$ & $-0.125^{* *}$ \\
\hline & $(0.061)$ & $(0.062)$ & $(0.060)$ & $(0.060)$ & $(0.060)$ & $(0.060)$ \\
\hline \multirow[t]{2}{*}{$\Delta \ln (\text { wage })_{\mathrm{pt}}$} & $-0.202 * * *$ & $-0.202 * * *$ & $-0.206^{* * *}$ & $-0.207 * * *$ & $-0.207 * * *$ & $-0.208 * * *$ \\
\hline & $(0.050)$ & $(0.050)$ & $(0.050)$ & $(0.050)$ & $(0.050)$ & $(0.050)$ \\
\hline \multirow{2}{*}{$\Delta \ln (\text { elect_price })_{\mathrm{pt}}$} & $-0.228 * *$ & $-0.236 * *$ & $-0.219 * *$ & $-0.200 * *$ & $-0.204 * *$ & $-0.213 * *$ \\
\hline & $(0.094)$ & $(0.094)$ & $(0.095)$ & $(0.093)$ & $(0.093)$ & $(0.095)$ \\
\hline \multirow[t]{2}{*}{$\Delta \ln (\text { population })_{\mathrm{pt}}$} & $0.436^{* *}$ & $0.447 * *$ & $0.446^{* *}$ & $0.497 * * *$ & $0.497 * * *$ & $0.481 * * *$ \\
\hline & $(0.187)$ & $(0.186)$ & $(0.187)$ & $(0.188)$ & $(0.188)$ & $(0.187)$ \\
\hline \multirow[t]{2}{*}{$\Delta \ln (\text { openness })_{\mathrm{pt}}$} & $0.077 * *$ & $0.076^{* *}$ & $0.075^{* *}$ & $0.075^{* *}$ & $0.074^{* *}$ & $0.074 * *$ \\
\hline & $(0.035)$ & $(0.035)$ & $(0.035)$ & $(0.035)$ & $(0.035)$ & $(0.035)$ \\
\hline \multirow{2}{*}{$\Delta \ln (\text { seaberths })_{\mathrm{pt}}$} & $0.006^{* * *}$ & $0.006^{* * *}$ & $0.006^{* * *}$ & $0.006^{* * *}$ & $0.006^{* * *}$ & $0.006^{* * *}$ \\
\hline & $(0.002)$ & $(0.002)$ & $(0.002)$ & $(0.002)$ & $(0.002)$ & $(0.002)$ \\
\hline \multirow[t]{2}{*}{$\Delta \ln (\text { riverberths })_{\mathrm{pt}}$} & -0.000 & -0.000 & 0.000 & 0.000 & 0.000 & 0.000 \\
\hline & $(0.000)$ & $(0.000)$ & $(0.000)$ & $(0.0001)$ & $(0.0001)$ & $(0.0001)$ \\
\hline \multirow[t]{2}{*}{$\Delta \ln (\text { rail })_{\mathrm{pt}}$} & $0.272 * * *$ & $0.272 * * *$ & $0.271 * * *$ & $0.268 * * *$ & $0.270 * * *$ & $0.268 * * *$ \\
\hline & $(0.090)$ & $(0.090)$ & $(0.090)$ & $(0.090)$ & $(0.090)$ & $(0.090)$ \\
\hline \multirow{2}{*}{\multicolumn{2}{|c|}{$\mathrm{H}_{0}: \beta_{\mathrm{MA} \_ \text {outer }}=0 ; \beta_{\mathrm{SA} \_ \text {outer }}=0$}} & & & $\mathrm{~F}=15.72$ & & \\
\hline & & & & $p$-value $=0$ & & \\
\hline \multirow[t]{2}{*}{$\mathrm{H}_{0}: \beta_{\text {MA_own }}=0 ; \beta_{\text {MA_outer }}=0$} & & & & $\mathrm{~F}=2.54$ & & \\
\hline & & & & $p$-value $=0.08$ & & \\
\hline \multirow{2}{*}{$\mathrm{H}_{0}: \beta \mathrm{S}_{\mathrm{A} \_ \text {own }}=0 ; \beta \mathrm{S}_{\mathrm{A} \_ \text {outer }}=0$} & & & & $F=16.61$ & & \\
\hline & & & & $p$-value $=0$ & & \\
\hline RSS & 27648.26 & 27650.52 & 27659.90 & 27626.60 & 27630.11 & 27649.49 \\
\hline Observations & 40116 & 40116 & 40116 & 40116 & 40116 & 40116 \\
\hline
\end{tabular}

Notes: a)* significant at 10\%; ** significant at 5\%; *** significant at 1\%; b) Robust standard errors corrected for clustering in parentheses; c) MA_outer and SAouter terms enter non-linearly as in equation (3.6). 
Table 5: Determinants of Foreign Entry - Extensions

\begin{tabular}{|c|c|c|c|c|c|c|}
\hline \multicolumn{7}{|c|}{ Dependent Variable: $\Delta(\mathrm{n})_{\mathrm{ipt}}$} \\
\hline & (1) & (2) & (3) & (4) & (5) & (6) \\
\hline & ols & ols & ols & nls & nls & $\mathrm{nls}$ \\
\hline \multirow{2}{*}{$\Delta \ln (\text { MA_own })_{\text {ipt }}$} & $0.130^{*}$ & & $0.200 * * *$ & 0.818 & & $1.380 * *$ \\
\hline & $(0.066)$ & & $(0.071)$ & $(0.760)$ & & $(0.663)$ \\
\hline \multirow[t]{2}{*}{ (MA_outer $)_{\mathrm{ipt}}^{\mathrm{c}}$} & & & & 0.290 & & 0.273 \\
\hline & & & & $(0.424)$ & & $(0.219)$ \\
\hline \multirow{2}{*}{$\Delta \ln (\text { SA_own })_{\text {ipt }}$} & $0.197 * * *$ & $0.239 * * *$ & & $1.019^{*}$ & $1.312^{* * *}$ & \\
\hline & $(0.052)$ & $(0.051)$ & & $(0.550)$ & $(0.514)$ & \\
\hline \multirow[t]{2}{*}{$(\text { SA_outer })_{\mathrm{ipt}}^{\mathrm{c}}$} & & & & 0.144 & 0.159 & \\
\hline & & & & $(0.124)$ & $(0.098)$ & \\
\hline \multirow[t]{2}{*}{$\Delta \ln (\text { SA_abroad })_{\mathrm{pt}}$} & $-0.271 * *$ & $-0.272 * *$ & $-0.275^{* *}$ & $-0.279 * * *$ & $-0.277 * * *$ & $-0.279 * * *$ \\
\hline & $(0.119)$ & $(0.120)$ & $(0.116)$ & $(0.117)$ & $(0.118)$ & $(0.116)$ \\
\hline \multirow[t]{2}{*}{$\Delta \ln (\text { wage })_{\mathrm{pt}}$} & $-0.474 * * *$ & $-0.475 * * *$ & $-0.481 * * *$ & $-0.475 * * *$ & $-0.476 * * *$ & $-0.479 * * *$ \\
\hline & $(0.086)$ & $(0.086)$ & $(0.086)$ & $(0.085)$ & $(0.086)$ & $(0.086)$ \\
\hline \multirow[t]{2}{*}{$\Delta \ln (\text { elect_price })_{\mathrm{pt}}$} & -0.226 & -0.238 & -0.212 & -0.178 & -0.189 & -0.197 \\
\hline & $(0.151)$ & $(0.150)$ & $(0.153)$ & $(0.149)$ & $(0.148)$ & $(0.152)$ \\
\hline \multirow[t]{2}{*}{$\Delta \ln (\text { population })_{\mathrm{pt}}$} & 0.505 & 0.518 & 0.498 & $0.591^{*}$ & $0.579 *$ & 0.555 \\
\hline & $(0.337)$ & $(0.337)$ & $(0.339)$ & $(0.341)$ & $(0.340)$ & $(0.341)$ \\
\hline \multirow[t]{2}{*}{$\Delta \ln (\text { openness })_{\mathrm{pt}}$} & $0.214 * * *$ & $0.213 * * *$ & $0.214 * * *$ & $0.208 * * *$ & $0.210 * * *$ & $0.209 * * *$ \\
\hline & $(0.063)$ & $(0.063)$ & $(0.062)$ & $(0.062)$ & $(0.062)$ & $(0.062)$ \\
\hline \multirow[t]{2}{*}{$\Delta \ln (\text { seaberths })_{\mathrm{pt}}$} & $0.006^{*}$ & $0.006^{*}$ & $0.006^{*}$ & $0.006^{*}$ & $0.006^{*}$ & $0.006^{*}$ \\
\hline & $(0.003)$ & (0.003) & $(0.003)$ & $(0.003)$ & $(0.003)$ & $(0.003)$ \\
\hline \multirow[t]{2}{*}{$\Delta \ln (\text { riverberths })_{\mathrm{pt}}$} & $-0.000 *$ & $-0.000^{*}$ & $-0.000^{*}$ & $-0.0002 * *$ & $-0.0002 * *$ & $-0.0002^{*}$ \\
\hline & $(0.000)$ & $(0.000)$ & $(0.000)$ & $(0.000)$ & $(0.000)$ & $(0.000)$ \\
\hline \multirow[t]{2}{*}{$\Delta \ln (\text { rail })_{\mathrm{pt}}$} & $0.814 * * *$ & $0.815^{* * *}$ & $0.812 * * *$ & $0.810 * * *$ & $0.813 * * *$ & $0.808 * * *$ \\
\hline & $(0.176)$ & $(0.175)$ & $(0.176)$ & $(0.175)$ & $(0.175)$ & $(0.175)$ \\
\hline \multirow[t]{2}{*}{$(\text { Distance_port })_{\mathrm{pt}}$} & $-0.042 * * *$ & $-0.042 * * *$ & $-0.040 * * *$ & $-0.045 * * *$ & $-0.044 * * *$ & $-0.042 * * *$ \\
\hline & $(0.011)$ & $(0.011)$ & $(0.011)$ & $(0.011)$ & $(0.011)$ & $(0.011)$ \\
\hline \multirow[t]{2}{*}{ (Total foreign } & $0.045 * * *$ & $0.046 * * *$ & $0.048 * * *$ & $0.044 * * *$ & $0.045 * * *$ & $0.046 * * *$ \\
\hline & $(0.011)$ & $(0.011)$ & $(0.011)$ & $(0.011)$ & $(0.011)$ & $(0.011)$ \\
\hline \multirow{2}{*}{\multicolumn{2}{|c|}{$\mathrm{H}_{0}: \beta_{\mathrm{MA} \_ \text {outer }}=0 ; \beta_{\mathrm{SA} \_ \text {outer }}=0$}} & & & $\mathrm{~F}=17.43$ & & \\
\hline & & & & $p$-value $=0$ & & \\
\hline \multirow{2}{*}{\multicolumn{2}{|c|}{$\mathrm{H}_{0}: \beta_{\mathrm{MA} \_ \text {own }}=0 ; \beta_{\text {MA_outer }}=0$}} & & & $\mathrm{~F}=3.73$ & & \\
\hline & & & & $p$-value $=0.02$ & & \\
\hline $\mathrm{H}_{0}: \beta \mathrm{S}_{\mathrm{A} \_ \text {own }}=0 ; \beta \mathrm{S}_{\mathrm{A}_{-} \text {outer }}=0$ & & & & $\begin{array}{r}\mathrm{F}=11.82 \\
p \text {-value }=0\end{array}$ & & \\
\hline RSS & 108306.81 & 108315.12 & 108328.53 & 108212.8 & 108232.9 & 108276.6 \\
\hline Observations & 44805 & 44805 & 44805 & 44805 & 44805 & 44805 \\
\hline
\end{tabular}

Notes: a)* significant at 10\%; ** significant at 5\%; *** significant at $1 \%$; b) Robust standard errors corrected for clustering in parentheses; c) MA_outer and SAouter terms enter non-linearly as in equation (3.6). 